\title{
THE EFFECT OF DIFFERENT TYPES OF ROOTSTOCK ON THE QUALITY OF MAIDEN TREES OF SWEET CHERRY (Prunus avium L.) cv. 'REGINA'
}

\author{
Piotr Baryła, Magdalena Kapłan, Marcela Krawiec \\ Department of Seed Production and Nurseries, University of Life Sciences in Lublin \\ Leszczyńskiego 58, 20-068 Lublin, Poland \\ e-mail: agric@ poczta.onet.pl,magdalena.kaplan@up.lublin.pl,marcela.krawiec@up.lublin.pl
}

Received: 16.12 .2014

\begin{abstract}
Over the period 2006-2009 in Lublin, a study was conducted to determine the effect of five types of rootstock: 'Colt', 'F12/1', sweet cherry (Prunus avium L.), 'GiSelA 5' and 'Piast' mahaleb cherry (Prunus mahaleb L.), on the growth and quality of maiden sweet cherry trees cv. 'Regina' in a commercial nursery. Based on the three-year average, rootstocks were shown to have a significant effect on the investigated quality characteristics of maiden sweet cherry trees. Trees budded on 'Colt' vegetative rootstock were characterized by strongest growth and best quality. In each year, they were thicker, higher and better branched than sweet cherries on the rootstock. Under the tested conditions, 'GiSelA 5' dwarf rootstock significantly reduced the growth and quality of budded sweet cherry trees in the nursery. During the period 2007-2009, no physiological incompatibility symptoms were observed 'Regina' sweet cherry cv. and 'Piast' seedling rootstocks. The growth of trees budded on 'Piast' mahaleb cherry was poorer than on 'Colt' clonal rootstock, but it was stronger than on 'F12/1' and Prunus avium L. rootstocks.
\end{abstract}

Key words: Prunus avium L., vegetative rootstock, seedling, growth, nursery

\section{INTRODUCTION}

A major problem in the production of sweet cherry (Prunus avium L.) is tree vigour [1,2]. Due to the large tree size, sweet cherry varieties grafted on traditional rootstocks are suitable mainly for extensive orchards. It is difficult to protect large trees, they create problems during fruit picking and usually reach the fruit-bearing stage quite late, thus increasing production costs. The intensification of sweet cherry growing should involve the production of trees on semi-dwarf and dwarf rootstocks or the use of dwarfing interstems [3-7]. An appropriately chosen rootstock has a significant effect not only on the growth of trees [8], but also on their quality [9], pre- cocity $[10,11]$, and fruit quality $[12,13]$. Prunus avium L. seedlings are the most frequently used rootstock for sweet cherry cultivars in Poland. Mahaleb cherry (Prunus mahaleb L.) [14-16], which can be propagated both from seed $[17,18]$ and vegetatively $[19,20]$, is of great importance in the production of sweet cherry trees in some countries. The share of mahaleb cherry in sweet cherry production in Poland is currently low. The major changes in sweet cherry growing methods which have been observed in recent years are a result of low-vigour vegetative rootstocks [21-24] whose main advantage, compared to seedlings, is their genetic homogeneity.

The aim of the present study was to determine the effect of five types of rootstock on the growth and quality of maiden trees of sweet cherry cv. 'Regina' in a nursery.

\section{MATERIALS AND METHODS}

The present study was carried out during the period 2006-2009 at the Felin Experimental Farm, belonging to the University of Life Sciences in Lublin. A field experiment was established on grey-brown podzolic soil, developed from marl-loess deposits and classified as soil class II. Three types of vegetative rootstocks: 'Colt', 'F12/1', 'GiSelA 5', as well as sweet cherry (Prunus avium L.) seedlings and a selective type of 'Piast' mahaleb cherry (Prunus mahaleb L.) were the subject of the present study. Rootstocks were planted in a nursery in early spring at a spacing of $90 \mathrm{~cm}$ × $25 \mathrm{~cm}(44,400$ rootstocks $\times$ ha $\left.^{-1}\right)$. Bud grafting was performed on $1 \mathrm{Au}-$ gust; buds of sweet cherry (Prunus avium L.) cv. 'Regina' were grafted on rootstocks $15 \mathrm{~cm}$ above the ground using chip budding. During the study period, the soil in the nursery was maintained as black fallow. No irrigation was used in the nursery, fertilization was applied 
based on soil analysis, whereas plant protection was carried out in accordance with the current recommendations resulting from the orchard crop protection schedule.

'Colt', 'F12/1' and 'Piast' rootstocks as well as sweet cherry seedlings came from the "Grzywa" Nursery Farm in Karczmiska, whereas 'GiSelA 5' clonal rootstock was purchased from the Fruit Experiment Station in Brzezna.

The experiment was set up in a randomized block design. It included 5 treatments in 5 replicates. Rootstock types were the treatments, while plots in which 100 plants were grown were replicates.

Before digging up the trees at the beginning of October, trunk diameter at a height of $30 \mathrm{~cm}$ from the place of budding and the height of maiden trees from the place of budding to the terminal bud were measured. The degree of branching of maiden trees was estimated by measuring lateral shoots with a length of more than $5 \mathrm{~cm}$ and recording their number. The measurements obtained were the basis for the calculation of the total length of sylleptic shoots and shoot length. The results were statistically analysed using analysis of variance and Tukey's confidence intervals. The significance of differences was determined at $\alpha=0.05$.

During the study period, there were large variations in weather conditions in particular years (Table 1). From January to September 2007, the mean monthly air temperatures were higher than the long-term means. The highest difference was recorded in January $(6.5 \mathrm{oC})$ and in March $\left(5.3^{\circ} \mathrm{C}\right)$. The lowest minimum air temperature $\left(-13.6^{\circ} \mathrm{C}\right)$ was recorded in the last 10-day period of February. In April ground frost occurred sporadically. Ground-level temperature decreases below $0 \mathrm{oC}$ that occurred at the beginning of May did not cause significant damage in the nursery. In the months of February, April, August, October and December, the total precipitation was lower than the long-term mean. Favourable weather conditions during the growing period promoted intensive plant growth.
In 2008 the mean monthly air temperatures were higher than the long-term average, except for May and September. The winter was warm and mild. The lowest minimum air temperature was recorded in the middle of February and it was $-13.2^{\circ} \mathrm{C}$, while at ground level $-15.9^{\circ} \mathrm{C}$. Slight ground frost occurred at the end of April. No subzero temperatures were recorded in May. In 2008 the warmest month was August with the average monthly air temperature of $19.8^{\circ} \mathrm{C}$. The amount of rainfall in particular months varied. After a wet spring (in March, April and May the total rainfall was higher than the long-term average), lower rainfall levels were recorded in the summer months of June, July and August (below the long-term average for this period). September, October and December of 2008 were characterized by higher total precipitation than the long-term mean for these months.

In the last year of the study, the most of mean monthly air temperatures were much higher than the long-term means. The mean monthly air temperatures were lower than the long-term average only in October and December of 2009. The highest difference in temperature was found in April $\left(4^{\circ} \mathrm{C}\right)$ and in September $\left(2.4^{\circ} \mathrm{C}\right)$. The warmest month of the year was July $\left(19.9^{\circ} \mathrm{C}\right)$, whereas the coldest one January $\left(-2.7^{\circ} \mathrm{C}\right)$. The lowest minimum air temperature was recorded in January and it was $-19.3^{\circ} \mathrm{C}$, while at ground level $-22.0^{\circ} \mathrm{C}$. Ground frost occurred in the first and second 10-day periods of April as well as in the second 10-day period of May, but it did not result in damage in the nursery. As regards the amount of precipitation, the year of 2009 varied substantially. In March and October the total rainfall was more than twice higher than the long-term average for these months. A large amount of rainfall was recorded in June (125.5 mm), nearly $58 \mathrm{~mm}$ more than the long-term average for this month. The total rainfall in April 2009 was only $2.9 \mathrm{~mm}$ and it was lower by $35.9 \mathrm{~mm}$ than the long-term mean. The amount of precipitation recorded in January, July, August and September was also lower than the long-term means.

Table 1

Mean monthly air temperatures and precipitation totals in 2007-2009 relative to the long-term means

\begin{tabular}{|c|c|c|c|c|c|c|c|c|}
\hline \multirow{3}{*}{ Month } & \multicolumn{4}{|c|}{ Temperature $\left({ }^{\circ} \mathrm{C}\right)$} & \multicolumn{4}{|c|}{ Total precipitation $(\mathrm{mm})$} \\
\hline & \multicolumn{3}{|c|}{ Monthly mean } & \multirow{2}{*}{ Long-term mean } & \multicolumn{3}{|c|}{ Monthly total } & \multirow{2}{*}{ Long-term mean } \\
\hline & 2007 & 2008 & 2009 & & 2007 & 2008 & 2009 & \\
\hline January & 2.6 & 0.4 & -2.7 & -3.9 & 51.5 & 36.2 & 20.2 & 25.4 \\
\hline February & -1.6 & 2.2 & -1.2 & -3.1 & 22.3 & 17.8 & 36.9 & 24.7 \\
\hline March & 6.2 & 3.4 & 1.4 & 0.9 & 30.2 & 64.8 & 69.6 & 25.0 \\
\hline April & 8.7 & 9.3 & 11.4 & 7.4 & 17.4 & 55.8 & 2.9 & 38.8 \\
\hline May & 15.1 & 12.8 & 13.6 & 13.0 & 80.5 & 101.6 & 71.1 & 58.5 \\
\hline June & 18.1 & 17.7 & 16.4 & 16.4 & 87.5 & 25.9 & 125.5 & 67.9 \\
\hline July & 19.2 & 18.3 & 19.9 & 17.7 & 87.0 & 77.1 & 57.1 & 77.8 \\
\hline August & 18.4 & 19.8 & 19.0 & 17.1 & 37.6 & 45.0 & 54.7 & 73.7 \\
\hline September & 13.0 & 12.6 & 15.3 & 12.9 & 129.8 & 102.2 & 21.0 & 46.4 \\
\hline October & 7.3 & 10.1 & 6.9 & 8.0 & 17.7 & 55.5 & 103.6 & 39.5 \\
\hline November & 1.0 & 4.8 & 5.5 & 2.7 & 31.3 & 33.1 & 43.1 & 39.9 \\
\hline December & -1.2 & 0.9 & -1.7 & -1.3 & 14.9 & 43.8 & 37.8 & 34.5 \\
\hline
\end{tabular}




\section{RESULTS}

In 2007 and 2008 sweet cherries on 'Colt' rootstock had a significantly larger trunk diameter than trees on the other types of rootstock (Table 2). In the case of 'GiSelA 5' semi-dwarfing rootstock, the trunk thickness was lowest.

Table 2

The effect of rootstocks on trunk diameter of maiden sweet cherry trees cv. 'Regina' in 2007-2009

\begin{tabular}{lccccccc}
\hline \multicolumn{1}{c}{ Rootstock } & 2007 & 2008 & 2009 & Mean & Differences between production cycles \\
\hline Colt & \multicolumn{7}{c}{ Diameter of maiden trees, mm } \\
F12/1 & $22.3 \mathrm{a}$ & $25.5 \mathrm{a}$ & $21.3 \mathrm{a}$ & $23.0 \mathrm{a}$ & $\mathrm{B}$ & $\mathrm{A}$ & $\mathrm{B}$ \\
Prunus avium L. & $15.3 \mathrm{~b}$ & $17.4 \mathrm{~b}$ & $16.3 \mathrm{~b}$ & $16.3 \mathrm{~b}$ & $\mathrm{~ns}$ ni & $\mathrm{ns}$ ni & $\mathrm{ns}$ ni \\
GiSelA 5 & $15.0 \mathrm{~b}$ & $19.3 \mathrm{~b}$ & $12.8 \mathrm{c}$ & $15.7 \mathrm{~b}$ & $\mathrm{~B}$ & $\mathrm{~A}$ & $\mathrm{~B}$ \\
Piast & $11.5 \mathrm{c}$ & $15.8 \mathrm{~b}$ & $15.5 \mathrm{~b}$ & $14.2 \mathrm{~b}$ & $\mathrm{~B}$ & $\mathrm{~A}$ & $\mathrm{~A}$ \\
\hline
\end{tabular}

Explanation: Means within the column followed by the same letter are not significantly different at $\alpha=0.05$; significant differences between production cycles at $\alpha=0.05$ are marked with capital letters.

In the last year of the experiment, trees budded on 'Colt' and 'Piast' rootstocks differed significantly in trunk thickness from trees grafted on sweet cherry seedlings as well as on 'GiSelA 5' and 'F12/1' clonal rootstocks.

In the case of ' $F 12 / 1$ ' rootstock, no significant differences were found between production cycles. Maiden trees produced on 'Colt' clonal rootstock and Prunus avium L. seedling rootstocks in the second year of the study had a significantly larger tree trunk than trees in the other years. As far as 'Piast' seedlings are concerned, there were significant differences between the years 2007 and 2009, while in the case of 'GiSelA 5 ' rootstock such differences were found between the first production cycle and the last two ones.

The study showed a significant effect of rootstocks on trunk diameter of maiden sweet cherry trees cv. 'Regina'. On average for the three-year period, trees on 'Colt' clonal rootstock differed significantly in thickness from trees budded on the following rootstocks: 'GiSelA 5', 'F12/1' and Prunus avium L. seedlings (Table 2).

Table 3

The effect of rootstocks on the height of maiden sweet cherry trees cv. 'Regina' in 2007-2009

\begin{tabular}{|c|c|c|c|c|c|c|c|}
\hline Rootstock & 2007 & 2008 & 2009 & Mean & \multicolumn{3}{|c|}{ Differences between production cycles } \\
\hline \multicolumn{8}{|c|}{ Height of maiden trees, $\mathrm{cm}$} \\
\hline Colt & $201.0 \mathrm{a}$ & $194.6 \mathrm{a}$ & $207.3 \mathrm{a}$ & $201.0 \mathrm{a}$ & ns ni & ns ni & ns ni \\
\hline $\mathrm{F} 12 / 1$ & $167.0 \mathrm{bc}$ & $169.7 \mathrm{~b}$ & $145.6 \mathrm{~b}$ & $160.7 \mathrm{~b}$ & A & A & B \\
\hline Prunus avium L. & $161.2 \mathrm{bc}$ & $164.3 \mathrm{~b}$ & $147.4 \mathrm{~b}$ & $157.6 \mathrm{~b}$ & ns ni & ns ni & ns ni \\
\hline GiSelA 5 & $147.6 \mathrm{c}$ & $135.7 \mathrm{c}$ & $156.2 \mathrm{~b}$ & $146.5 \mathrm{~b}$ & $\mathrm{AB}$ & B & A \\
\hline Piast & $176.2 \mathrm{ab}$ & $161.5 \mathrm{~b}$ & $189.8 \mathrm{a}$ & $175.8 \mathrm{ab}$ & $\mathrm{AB}$ & B & A \\
\hline
\end{tabular}

Explanation: Means within the column followed by the same letter are not significantly different at $\alpha=0.05$; significant differences between production cycles at $\alpha=0.05$ are marked with capital letters.

In the first year of production, significant differences were shown between 'Colt' rootstock versus 'GiSelA 5' clone, 'F12/1' and sweet cherry seedlings (Table 3). Significant differences in the height of maiden trees were also found between trees budded on 'GiSelA 5' and 'Piast' rootstocks.

In 2008 trees budded on 'Colt' rootstock were significantly higher than those grafted on the other types of rootstock. Maiden trees on 'GiSelA 5' dwarf rootstock were significantly lowest.

In the last year of the study, significantly the highest sweet cherries were obtained on 'Colt' and 'Piast' rootstocks, whereas the lowest ones on 'F12/1', sweet cherry seedlings and 'GiSelA 5'.

In the case of two types of rootstock, 'Colt' and Prunus avium L., no significant differences were found 
between years. On 'F12/1' clonal rootstock, trees were significantly higher in the first two production cycles, whereas on 'GiSelA 5' and 'Piast' rootstocks there were significant differences in tree height between the years 2008 and 2009.
During the period 2007-2009, rootstocks were found to have a significant effect on the height of maidens in the nursery. On average, trees on 'Colt' rootstock were higher than trees budded on 'GiSelA 5', Prunus avium L. and 'F12/1' (Table 3).

Table 4

The effect of rootstocks on the total length of lateral shoots of maiden sweet cherry trees cv. 'Regina' in 2007-2009

\begin{tabular}{|c|c|c|c|c|c|c|c|}
\hline Rootstock & 2007 & 2008 & 2009 & Mean & \multicolumn{3}{|c|}{ Differences between production cycles } \\
\hline \multicolumn{8}{|c|}{ Total length of lateral shoots per tree, $\mathrm{cm}$} \\
\hline Colt & $480.1 \mathrm{a}$ & $384.2 \mathrm{a}$ & $239.7 \mathrm{a}$ & $368.0 \mathrm{a}$ & A & $\mathrm{AB}$ & $\mathrm{B}$ \\
\hline $\mathrm{F} 12 / 1$ & $221.4 \mathrm{bc}$ & $246.9 \mathrm{~b}$ & $150.1 \mathrm{~b}$ & $206.1 \mathrm{ab}$ & $\mathrm{AB}$ & A & $\mathrm{B}$ \\
\hline Prunus avium $\mathrm{L}$. & $276.4 \mathrm{bc}$ & $262.8 \mathrm{~b}$ & $140.1 \mathrm{~b}$ & $226.4 \mathrm{ab}$ & A & A & B \\
\hline GiSelA 5 & $142.9 \mathrm{c}$ & $201.6 \mathrm{~b}$ & $137.6 \mathrm{~b}$ & $160.7 \mathrm{~b}$ & $\mathrm{~B}$ & A & $\mathrm{B}$ \\
\hline Piast & $325.1 \mathrm{ab}$ & $380.7 \mathrm{a}$ & $263.1 \mathrm{a}$ & $322.9 \mathrm{ab}$ & $\mathrm{AB}$ & A & $\mathrm{B}$ \\
\hline
\end{tabular}

Explanation: Means within the column followed by the same letter are not significantly different at $\alpha=0.05$; significant differences between production cycles at $\alpha=0.05$ are marked with capital letters.

In 2007 trees budded on 'GiSelA 5', 'F12/1' and Prunus avium L. rootstocks had a significantly smaller total length of lateral shoots than on 'Colt' rootstock (Table 4). There were also significant differences between trees on 'GiSelA 5' clonal rootstock and on 'Piast' rootstock.

In the last two years, cv. 'Regina' sweet cherries grafted on 'Piast' seedlings and 'Colt' rootstock had a significantly greater total length of sylleptic shoots than on the other rootstock types.

Significant differences were shown between production cycles. Maiden trees produced in 2009 had a significantly smaller total length of lateral shoots than trees in the other years, except for sweet cherry trees on 'F12/1', 'GiSelA 5' and 'Piast' rootstocks in the first year of the study and on 'Colt' rootstock in the second production cycle.

The used rootstocks significantly affected the total length of lateral shoots. On average for the three-year period, sweet cherries on "Colt" rootstock were characterized by a significantly greater total length of sylleptic shoots than in trees on the 'GiSelA 5' clone (Table 4).

Table 5

The effect of rootstocks on the number of lateral shoots of maiden sweet cherry trees cv. 'Regina' in 2007-2009

\begin{tabular}{lccccccc}
\hline \multicolumn{1}{r}{ Rootstock } & 2007 & 2008 & 2009 & Mean & Differences between production cycles \\
\hline Colt & \multicolumn{7}{c}{ Number of lateral shoots per tree } \\
F12/1 & $8.7 \mathrm{a}$ & $4.9 \mathrm{ab}$ & 3.2 & 5.6 & $\mathrm{~A}$ & $\mathrm{~B}$ & $\mathrm{~B}$ \\
Prunus avium L. & $4.3 \mathrm{bc}$ & $3.9 \mathrm{ab}$ & 3.1 & 3.8 & $\mathrm{~ns} \mathrm{ni}$ & $\mathrm{ns}$ ni & $\mathrm{ns}$ ni \\
GiSelA 5 & $6.1 \mathrm{~b}$ & $4.3 \mathrm{ab}$ & 2.7 & 4.4 & $\mathrm{~A}$ & $\mathrm{~B}$ & $\mathrm{C}$ \\
Piast & $2.8 \mathrm{c}$ & $3.5 \mathrm{~b}$ & 3.4 & 3.2 & $\mathrm{~ns} \mathrm{ni}$ & $\mathrm{ns}$ ni & $\mathrm{ns}$ ni \\
\hline
\end{tabular}

Explanation: Means within the column followed by the same letter are not significantly different at $\alpha=0.05$; significant differences between production cycles at $\alpha=0.05$ are marked with capital letters.

In 2007 trees budded on 'Colt' rootstock produced significantly more lateral shoots than on the other rootstock types (Table 5). Significantly the lowest number of sylleptic shoots was found in sweet cherry trees budded on 'GiSelA 5' clonal rootstock.

In the second year of the study, there were significant differences in the number of lateral shoots between 'Piast' seedling rootstock and 'GiSelA 5' rootstock.

Significant differences between production cycles were revealed for three rootstock types. In the first year of the study, maiden trees grafted on the 'Colt' vegetative clone and Prunus avium L. seedlings produced a higher number of lateral shoots than in the other 
years. In the case of 'Piast' rootstock, significant differences were found in the first and second production cycles versus the last one.

The statistical analysis of the mean for the study period did not find rootstocks to significantly affect the number of lateral shoots in sweet cherry cv. 'Regina'. Significant differences were only shown in the first and second years of the experiment (Table 5).

Table 6

The effect of rootstocks on the average length of lateral shoots of maiden sweet cherry trees cv. 'Regina' in 2007-2009

\begin{tabular}{|c|c|c|c|c|c|c|c|}
\hline Rootstock & 2007 & 2008 & 2009 & Mean & \multicolumn{3}{|c|}{ Differences between production cycle } \\
\hline \multicolumn{8}{|c|}{ Shoot length, cm } \\
\hline Colt & 54.2 & $78.8 \mathrm{a}$ & $74.4 \mathrm{a}$ & $69.2 \mathrm{a}$ & $\mathrm{B}$ & A & A \\
\hline $\mathrm{F} 12 / 1$ & 52.1 & $65.8 \mathrm{a}$ & $48.9 \mathrm{~b}$ & $55.6 \mathrm{ab}$ & ns ni & ns ni & ns ni \\
\hline Prunus avium L. & 45.7 & $61.8 \mathrm{a}$ & $51.5 \mathrm{~b}$ & $53.0 \mathrm{ab}$ & $\mathrm{B}$ & A & $\mathrm{AB}$ \\
\hline GiSelA 5 & 51.2 & $43.0 \mathrm{~b}$ & $41.3 \mathrm{~b}$ & $45.2 \mathrm{~b}$ & ns ni & ns ni & ns ni \\
\hline Piast & 59.5 & $69.2 \mathrm{a}$ & $72.4 \mathrm{a}$ & $67.0 \mathrm{ab}$ & $\mathrm{B}$ & $\mathrm{AB}$ & A \\
\hline
\end{tabular}

Explanation: Means within the column followed by the same letter are not significantly different at $\alpha=0.05$; significant differences between production cycles at $\alpha=0.05$ are marked with capital letters.

In the second year of the study, trees budded on 'GiSelA 5' dwarf rootstock produced significantly the shortest lateral shoots (Table 6).

In 2009 trees produced significantly longer sylleptic shoots on the 'Colt' and 'Piast' seedling rootstocks than on Prunus avium L. or on 'GiSelA 5' and 'F12/1' vegetative rootstocks.

No significant differences between production cycles were found in the case of 'F12/1' and 'GiSelA 5 ' clonal rootstocks. In the first year, trees budded on 'Colt' rootstock had significantly shorter lateral shoots than trees in the other years. In the case of trees budded on sweet cherry seedlings there were significant differences between 2007 and 2008, whereas for 'Piast' rootstock significant differences were found between the first and last production cycles.

On average for the period 2007-2009, sweet cherry trees budded on 'Colt' rootstock significantly differed in lateral shoot length from trees on 'GiSelA 5 ' clonal rootstock (Table 6).

\section{DISCUSSION}

Fruit trees most frequently consist of two elements: a rootstock and a scion grafted on it. In the case of sweet cherry, which is characterized by strong growth, a third element in the form of a dwarfing interstem is sometimes introduced and it is designed to weaken tree vigour [3-7]. The interactions of all these elements are a complex process and not fully known. The effect of rootstock on the growth of trees in an orchard is different than in the case of budded trees in a nursery. This phenomenon is associated with a different capacity of rootstocks to overcome stresses and with a short production cycle in a nursery [25].
An appropriately chosen rootstock affects both the growth $[8,26]$ and quality of trees $[9,27]$. For the purpose of comparison, the experiment tested rootstocks commonly used in Poland for the production of sweet cherry trees: Prunus avium L. seedlings, 'Colt' and 'F12/1' rootstocks $[6,26]$ as well as the 'GiSelA 5' which is considered to be one of the most valuable rootstocks for sweet cherry $[21,28]$. The study also used mahaleb cherry; in the case of this cherry, the opinions on its usefulness as rootstock for sweet cherry cultivars vary and this divergence of opinion arises from the possibility of occurrence of physiological incompatibility [6,17,29].

Prunus avium L. seedling rootstock as well as 'F12/1' and 'Colt' clonal rootstocks belong to the most vigorous rootstocks used in the production of sweet cherry trees $[4,6,30]$. On average for the threeyear period, trees budded on 'Colt' rootstock were significantly thicker and significantly higher than trees on sweet cherry seedlings as well as on 'F12/1' and 'GiSelA 5' rootstocks. Studying the effects of two rootstocks on the growth parameters and efficiency of budded trees of the following sweet cherry cultivars: 'Johana', 'Kordia' and 'Regina', S t a c h o w i a k and Świerczyński [26] obtained different results. They demonstrated that cv. 'Regina' trees on 'F12/1' rootstock had a significantly larger trunk diameter and height than trees budded on the 'Colt'. In the opinion of the above-cited authors, the level of impairment of vigour in trees budded on 'Colt' rootstock was dependent on the cultivar. In his experiment, M a ć k o w i a k also observed [31] a stronger growth of sweet cherry trees cvs. 'Hedelfińska', 'Bütnera Czerwona' and 'Rivan' budded on 'F12/1' compared to 'Colt' rootstock. Sweet cherry is commonly considered to be a more 
vigorous rootstock than mahaleb cherry. According to $\mathrm{Grzyb}$ [6], it is possible to grow sweet cherry trees on mahaleb cherry seedling rootstocks on the condition that trees with physiological incompatibility symptoms are eliminated from the nursery. During the period 2007-2009 in the nursery, no incompatibility symptoms were observed in cv. 'Regina' sweet cherry trees budded on 'Piast' mahaleb cherry rootstock. On average for the three-year period as well as in the first and second years of the study, no significant differences were found in the quality of budded trees on Prunus avium L. seedlings and 'Piast' rootstock. Significant differences were shown in 2009, since trees on 'Piast' mahaleb cherry rootstock had a significantly larger trunk diameter and height than trees budded on sweet cherry seedling rootstocks. Two types of mahaleb cherry selected in Poland, 'Piast' and 'Popiel', are characterized by strong growth [17]. The use of these seedlings in sour cherry production substantially improves tree quality [32]. Different selective types of mahaleb cherry are used in sweet cherry production across the world [5,6,18]. As shown by numerous studies [3-7], in growing sweet cherries the future belongs to dwarf and semi-dwarf rootstocks as well as to semi-dwarfing interstems. 'GiSelA 5', among others, is included in rootstocks that most strongly reduce tree growth $[28,33]$. In the present experiment, cv. 'Regina' sweet cherry trees grafted on 'GiSelA 5' rootstock were characterized by the poorest growth in the nursery and their quality was lowest. It should be stressed that the poorer growth of sweet cherry trees on 'GiSelA 5' rootstock in the nursery, compared to other types of rootstock, cannot be a ground for discontinuing the production of maiden trees on this rootstock. Sweet cherry production on 'GiSelA 5' rootstocks yields good results in orchards; 'GiSelA 5' is considered to be one of the most valuable rootstocks $[21,28]$ and plays an important role in the intensification of sweet cherry growing across the world.

The vigour and branching of budded trees are determined by the rootstock and cultivar characteristics [34]. According to $S \mathrm{c} \mathrm{z}$ e p a ń s k i and R e j m a n [35], the total length of annual shoots and their average length are one of better indicators for the growth of young trees. Three-year measurements of branching in budded trees showed differences between individual rootstock types. On average, trees on high-vigour 'Colt' rootstock were characterized by significantly the greatest total length of lateral shoots and their average length, whereas these parameters were lowest for 'GiSelA 5' clonal rootstock. In their study, S t a chowiak and Świerczyński observed 'Colt' rootstock to have a significant effect on branching of maiden sweet cherry trees grown in a nursery [36]. In each year of the experiment, 'Regina' trees on 'Piast' seedling rootstocks were better branched than trees budded on sweet cherry seedlings, 'F12/1' and 'GiSelA 5'. In the opinion of Li p e c k i [37], in apple the rootstock has a greater effect on the formation of sylleptic shoots than the cultivar. Rootstocks were shown to significantly affect the number of lateral shoots only in two years during the three-year study period. In 2007 trees on 'Colt' rootstock produced significantly the greatest number of shoots, while in 2008 those on on 'Piast' seedling rootstock. S t a c h ow iak and Świerczyński [26] obtained a significantly higher number of long shoots in cv. 'Regina' sweet cherry trees budded on 'Colt' than on 'F12/1'.

In the present study, in some cases different results were obtained than those reported in the currently available literature, which might be caused by different site and weather conditions.

\section{CONCLUSIONS}

1. Based on the three-year average, rootstocks were shown to have a significant effect on the investigated quality characteristics (trunk diameter, height, total length of lateral shoots, average shoot length) of maiden sweet cherry trees cv. 'Regina' in the nursery.

2. Trees budded on 'Colt' vegetative rootstock were characterized by strongest growth and best nursery quality; in each year, they were thicker, higher and better branched than sweet cherries on the other rootstock.

3. Under the tested conditions, 'GiSelA 5' dwarf rootstock significantly reduced the growth and length of laterals shoots of budded sweet cherry trees in the nursery. Breeders that decide to grow sweet cherries on 'GiSelA 5' rootstocks should take into account the poor growth of trees in the nursery and apply appropriate aftercare in the first years after the establishment of an orchard.

4. During the period 2007-2009, no physiological incompatibility symptoms were observed between sweet cherry cv. 'Regina' and 'Piast' seedling rootstocks. The growth of trees budded on 'Piast' mahaleb cherry was poorer than on 'Colt' clonal rootstock, but it was stronger than on 'F12/1' and Prunus avium L. rootstocks.

\section{Acknowledgements}

Research supported by the Ministry of Science and Higher Education of Poland as part of the statutory activities of the Department of Seed Production and Nurseries, University of Life Sciences in Lublin.

\section{Authors' contributions}

The following declarations about authors' contributions to the research have been made: concept of 
the study: $\mathrm{PB}$; field research: $\mathrm{PB}, \mathrm{MK}, \mathrm{MK}$; data analyses: $\mathrm{PB}, \mathrm{MK}$; references: $\mathrm{PB}, \mathrm{MK}$; writing the manuscript: $\mathrm{PB}$.

\section{REFERENCES}

1. Kurlus R. Rootstock effects on growth, yield and fruit quality of two sweet cherry cultivars in Western Poland. Acta Hortic. 2008; 795: 293-298.

2. Hrotkó K, Magyar L, Gyeviki M. Effect of rootstocks on growth and yield of "Carmen" $®$ sweet cherry. Bull Univ Agric Sci Vet Med Cluj-Napoca Hortic. 2010; 66(1): 143-148.

3. Grzyb ZS, Zagaja SW, Zdyb J. Growth and yield of sweet cherry trees with interstem. Acta Hortic. 1985; 169: 59-64.

4. Callesen O. Recent developments in cherry rootstock research. Acta Hortic. 1998; 468: 219-228.

5. We bster AD. Strategies for controlling the size of sweet cherries trees. Acta Hortic. 1998; 468: 229-239.

6. Grzyb ZS. Rola podkładki i wstawki w regulowaniu wzrostu i owocowania drzew czereśni. Zesz Nauk AR Krakow. 1999; 66: 11-21.

7. Rozpara E, Grzyb ZS. Frutana - a new interstock for sweet cherry trees. Acta Hortic. 2004;658(1):247-250.

8. Cordeiro V, Sant os A. Sweet cherry growth and early bearing on different rootstocks. Acta Hortic. 2007; 732: 325-328.

9. Baryła P, Kapłan M, Krawiec M, Kiczorowski $\mathrm{P}$. The effect of rootstocks on the efficiency of a nursery of sweet cherry (Prunus avium L.) trees cv. 'Regina'. Acta Agrobot. 2014; 66(4): 121-128. http://dx.doi.org/ 10.5586/aa.2013.058

10. Hrotkó K. Advances and challenges in fruit rootstock research. Acta Hortic. 2007; 732: 33-42.

11. Gratacos E, Cores A, Kulczewski BM. Rootstock effects in two sweet cherry cultivars in Central Chile. Acta Hortic. 2008; 795: 227-237.

12. Simon G, Hrotkó K, Magyar L. Fruit quality of sweet cherry cultivars grafted on four different rootstocks. Acta Hortic. 2004; 658: 365-370.

13. De Salvador FR, di Tomaso G, Bonofiglio P, Piccioni C. Performance of new and standard cherry rootstocks in different soils and climatic conditions. Acta Hortic. 2005; 667: 191-200.

14. Lanauskas J, Kviklys D, Uselis N. Evaluation of rootstocks for sweet cherry cv. 'Vytenu Rozine'. Acta Hortic. 2004; 732: 335-339.

15. Seker M. Investigation of izosyme polymorphism in open-pollinated sweet cherry and 'Mahaleb' seedlings. Acta Hortic. 2008; 795: 423-428.

16. Sansavini S, Lugli S. Sweet cherry breeding programs in Europe and Asia. Acta Hortic. 2008; 795: 41-58.

17. Grzyb Z S. New rootstocks of stone fruit trees selected in Skierniewice. Acta Hortic. 2004; 658: 487-489.
18. García C, Jordano P, Godoy JA. Contemporary pollen and seed dispersal in a Prunus mahaleb population: patterns in distance and direction: pollen and seed dispersal patterns in Prunus mahaleb. Mol Ecol. 2007; 16(9): 1947-1955.http://dx.doi.org/10.1111/j.1365-294X.2006.03 126.x

19. Laurie P, Claverie J. Developments in high density cherries in France: integration of tree architecture and manipulation. Acta Hortic. 2005; 667: 285-292.

20. Magyar L, Hrotkó K. Effect of BA (6-benzyladenine) and $\mathrm{GA}_{4+7}$ on feathering of sweet cherry cultivars in the nursery. Acta Hortic. 2005; 667: 417-422.

21. Robinson TL. Performance of Cornell-Geneva rootstocks in the multi location NC-140 rootstock trials across North America. Acta Hortic. 2004; 658: 241-246.

22. Long L, Facteau T, Nunez-Elisea R, Cahn $\mathrm{H}$. Developments in high density cherries in the USA. Acta Hortic. 2005; 667: 303-310.

23. Paprstein F, Kloutvor J, Sedlak J. P-HL dwarfing rootstocks for sweet cherries. Acta Hortic. 2008; 795: 299-302.

24. S te h r R. Further experiences with dwarfing sweet cherry rootstocks in Northern Germany. Acta Hortic. 2008; 795: 185-190.

25. Poniedziałek W, Szczygieł A, Porębski S, Górski A. Wpływ terminu okulizacji i podkładki na przyjęcie się oczek i wzrost okulantów dwóch odmian jabłoni. Zesz Nauk AR W Krakowie Ogrod. 1997; 23: 5-18.

26. Stachowiak A, Świerczyński S. The effect of Colt and F12/1 rootstocks on growth and efficiency of young sweet cherry trees cultivars: 'Johana', 'Kordia' and 'Regina'. Rocz AR Pozn. 2001; 34: 93-99.

27. Milošević T, Milošević N. Growth and branching of pear trees (Pyrus domestica, Rosaceae) in nursery. Acta Sci Pol Hortorum Cultus. 2010; 9(4): 193-205.

28. Bujdoso G, Hrotkó K. Achievement of rootstock-scion interactions on dwarfing cherry rootstocks in Hungary. Hortic Sci. 2005; 32(4): 129-137.

29. Vegvari GY, Hrotkó K, Magyar L, Hajagos A, Csigai K. Histological investigation of cherry rootstocks. Acta Hortic. 2008; 795: 339-344.

30. Grzyb ZS, Sitarek M, Lis J. Wzrost i owocowanie czereśni szczepionych na różnych podkładkach wegetatywnych. Rocz AR Pozn. 2000; 31(2): 51-56.

31. Maćkowiak M. Obserwacje przydatności podkładek dla odmian czereśni. Rocz AR Pozn Ogrod. 1993;21:71-77.

32. Grzyb ZS. Nowe podkładki drzew pestkowych otrzymane w Instytucie Sadownictwa i Kwiaciarstwa w Skierniewicach. In: Materiały VIII ogólnopolskiego zjazdu naukowego hodowców roślin ogrodniczych "Hodowla roślin ogrodniczych u progu XXI wieku”. Lublin: 1999. p. 271-274.

33. Bujdoso G, Hrotkó K, Stehr R. Evaluation of sweet and sour cherry cultivars on German dwarfing rootstocks in Hungary. J Fruit Ornam Plant Res. 2004; 12: 233-244. 
34. Hrotkó K, Füzessery A. Effect of rootstock on the branching and quality of cherry trees in the nursery. Acta Hortic. 1996; 410: 507-509.

35. Szczepański K, Rejman S. Metodyka badań sadowniczych. Warsaw: PWRiL; 1987.

36. Stachowiak A, Świerczyński S. Growth of six sweet cherry cultivars on Colt and on Prunus avium L. rootstocks in a nursery. Rocz AR Pozn. 2004; 38: 149-156.

37. Lipecki J. Wpływ ściółkowania gleby w szkółce okulantów jabłoni. Ann UMCS Sec E. 1994; 2: 135-143.

\section{Wpływ różnych typów podkładek na jakość okulantów czereśni (Prunus avium L.) odmiany 'Regina'}

Streszczenie

W latach 2006-2009 w Lublinie wykonano badania, których celem była ocena wpływu pięciu typów podkładek: 'Colt', 'F12/1', czereśnia ptasia (Prunus avium L.), 'GiSelA 5' i antypka (Prunus mahaleb L.) 'Piast' na wzrost i jakość okulantów czereśni odmiany 'Regina' w szkółce produkcyjnej. Na podstawie średniej z trzech lat wykazano istotny wpływ podkładek na badane cechy jakościowe okulantów czereśni. Na podkładce wegetatywnej 'Colt' drzewka charakteryzowały się najsilniejszym wzrostem i najlepszą jakością. W każdym roku były grubsze, wyższe i lepiej rozgałęzione od czereśni na pozostałych typach podkładek. W badanych warunkach karłowa podkładka 'GiSelA 5' istotnie ograniczała wzrost i jakość okulantów czereśni w szkółce. W latach 2007-2009 nie zaobserwowano objawów niezgodności fizjologicznej u czereśni odmiany 'Regina' na siewkach 'Piast'. Wzrost drzewek na antypce 'Piast' był słabszy niż na klonie 'Colt' natomiast silniejszy, niż na podkładkach 'F12/1' i Prunus avium L.

Handling Editor: Elżbieta Weryszko-Chmielewska

This is an Open Access digital version of the article distributed under the terms of the Creative Commons Attribution 3.0 License (creativecommons.org/licenses/by/3.0/), which permits redistribution, commercial and non-commercial, provided that the article is properly cited.

(CThe Author(s) 2014 Published by Polish Botanical Society 